\title{
On the epistemology of postmodern spirituality
}

Author:
Dudley A. Schreiber ${ }^{1}$
Affiliation:
'Department of Christian
Spirituality, University of
South Africa, South Africa
Correspondence to:
Dudley Schreiber
Email:
dasch101@gmail.com
Postal address:
81 10th Street, Orange Grove
2192, South Africa
Dates:
Received: 26 May 2010
Accepted: 31 May 2011
Published: 17 Feb. 2012
How to cite this article:
Schreiber, D.A., 2012,
'On the epistemology of
postmodern spirituality',
Verbum et Ecclesia $33(1)$, Art.
\#398, 8 pages. http://dx.doi.
org/10.4102/ve.v33i1.398

(C) 2012. The Authors. Licensee: AOSIS OpenJournals. This work is licensed under the Creative Commons Attribution License.
At first glance, the postmodern spiritual 'scene' appears 'sociologically messy, experiential, multifaceted, ecological, provisional and collective' (Petrolle 2007) and of uncertain epistemic provenance. Here, I ask: can Roland Benedikter's (2005) conception of postmodern dialectic and spiritual turn, help us understand postmodern spirituality and can it assist in a construction of a postmodern epistemology of spirituality? The current argument constitutes a metatheoretical exploration of:

- Deconstruction and neo-essentialism as representing the significant dialectic in philosophical postmodernism. Deconstruction is presented as an apophatic moment in Western thought about 'knowing' and 'being' whilst postmodern neo-essentialism, though contextualised by antirealism and ambiguity, palpably suggests itself.

- Postmodern trends which derive from the dialectic.

- How these epistemic trends influence methodology in the study of spirituality.

- How a trans-traditional (anthropological) spirituality might incorporate insights about transformation from a complex of epistemologies in which, theories of 'self' abound.

In the conclusion an attempt is made to describe how postmodern spirituality expresses itself in society.

\section{Introduction}

\section{Postmodern spiritual turn as the epistemic context for postmodern spirituality}

If spirituality is at all times embedded in its time and place in the world and takes its language of meaning ascription from context (Lesniak 2005:7; Corkery 2005:26), how might postmodern insight enrich a contemporary understanding of spirituality across the 'three worlds' of knowledge (Mouton 2011:137), namely meta, epistemic and lay? Might postmodern philosophy be said to exhibit rational parallels to dynamics within trans-traditional spirituality? What experience of truth are we to speak of and how are we to speak of it? How might postmodern discourse on knowledge inform us about the experiential inward path of knowing characteristic of mysticism (McGinn 2005:19)? Thinking about spirituality, as do Schneiders (2005:1) and Sheldrake (2005:38), implicates us in contemporary myth, epistemology and general science. Elements of postmodern epistemic landscape suggest a sense of reality that confronts us 'with the enigma of existence itself' (Benedikter 2007:5) and the many challenges to knowing anything. Yet how might academic spirituality, relatively newly ensconced in the Human Sciences, build theory that is truly contemporary?

\section{Postmodern epistemic trends}

Although no universal agreement and no monolithic Postmodern Epistemology exist, Benedikter (2005) suggests the primary dialectic lies between deconstructionism (late 1970s to about the late 1990s) and a later constructivist neo-essentialism from 2001 onwards. Deconstruction as a trend, targets both premodern notions of metaphysics and ontology, and modernist realism, in a wide range of narratives. Narratives receiving greatest attention include rationalism, logical positivism, determinism and a gamut of progressively aggressive, externalist and positivist-styled creeds and paradigms (hegemonies) of materialism and domination, which had found their expression through the three worlds of knowledge and across the Western epistemic landscape. The meteoric rise of post-structural critique in the works of the French School of Continental Philosophy up to Foucault constituted a profound attack on former confidence in how history and society work. Furthermore, with the publication of Thomas Kuhn's (1962) The Structure of Scientific Revolutions (cf. also Bird 2004), Modernism's pride in Physical Science as its chosen and privileged epistemology came under devastating scrutiny. Lest we over simplify the epistemic picture, Griffiths (2007:1) suggests that not all sciences suffered to the same extent, noting a rise in interest in the philosophy of biology, which seems to have undergone some linguistic turn. The work of Bradie and Harms (2008) suggests that a contemporary epistemology of evolution posits a mitigated realism, freer 
from deterministic mindset. Perhaps, presumption of this less deterministic stance accounts for the way some lay conversations about spirituality indulge in naive biologism, and strange notions of evolutionary transformation? The quest for biochemical substrates remains fascinating at a popular level readily informed by science media. Perhaps too, a heightened sense of democracy in the world of lay knowledge provides an appeal to ontologise from below rather than from meta-engagement?

\section{Epistemic parallels? Deconstruction and apophasis}

Deconstruction as an epistemic trend seems to be a conscious and rational pursuit reminiscent of many traditional spiritual practices that aim to 'dissolve' ego-constructs in the history of Christian and Oriental spiritual practice. This in itself suggests at least a superficial parallel in the dynamics of postmodernism and spirituality. It could be argued that despite the numerous obstacles to a glib comparison, both philosophical deconstruction and spiritual dissolution of ego ultimately shadow each other by rendering purely rational knowing somewhat mute, truncated, if not counter-intuitive. Is it an over-generalisation to suggest that the postmodern revolution has brought epistemology close to apophatic crisis? What of the broader context of trans-traditional spirituality in which muteness is enhanced by the influence of Oriental meontic and antirealist thought in the Buddhist strands of Pacific philosophy?

\section{Constructive ontologising}

In contra-distinction to deconstruction, Benedikter (2005) claims that post-structural neo-essentialism is evident in a 'broad church' of thinkers and writers. These, he claims, suggest an ontological realism arising from a boundary of cognitive resistance to deconstructive finality. In paradoxical continuation of deconstructionism, constructive trend exhibits an epistemological project towards a protoontology, proto-realism and a proto-spirituality inspired by both oriental and postmodern antirealism. In contrast to essentialist fixity in premodern metaphysics, post-structural neo-essentialism perceives humanity's vital consciousness as dynamic, evolving and transforming. Cognitive turn seems to provide a shared locus of interest for traditionally divergent, unengaged epistemologies. Interdisciplinary inspiration in Wilber's (1995) Integral Theory, for instance, shows a multistrand, multihemisphere epistemology at play in trans-traditional spirituality.

\section{Postmodern epistemic dynamics Interplay and integralism}

It would seem apparent to minds like Benedikter's (2005) that a conciliatory dynamic within postmodernism is evident and necessary to negotiate an epistemological way forward. In order to re-imagine reality, we should draw on as many epistemic resources as possible. The cumulative opportunity presented in postmodern epistemic landscape, the result of multidimensional interplay between deconstructive and constructive intentions, has relaxed Western epistemological space: at once, democratising paradigmatic relationships in the sciences and providing greater proximity (and access to) particularised truths at lay level. In the worlds of both lay and scientific knowledge, a mildly constructivist re-imagination of epistemology finds itself more accommodated. At metalevel we are perhaps more open to Integral Theory (Wilber 1995).

\section{Un-grounding of being and spiritual core}

At its primary level, deconstructive postmodernism signals an un-grounding of traditional Western ontology and realism. Yet on the other hand, we readily embrace theoretical constructs of cognitive, intellectual and moral development in human sciences. It seems that Benedikter's claim of interplay between deconstruction and proto-constructivism within postmodernism bares some consideration. The constructivist intention is readily visible in theoretical science, especially those proposing developmental theories of cognition, consciousness and intelligence (Crain 1985). Cognitive science has produced a plethora of stage, state and realm theories. Nevertheless, a comprehensive understanding of spiritual core remains somewhat elusive and consequently no all-encompassing picture of spiritual transformation seems possible. This is not to say that epistemic proximity of ontic and meontic inspiration, do not enrich our quest. A fundamental concern lies with reductive approaches. The relatively open attitude to multiparadigm participation in our constructivist intent invigorates engagement with phenomenology. However, it might be argued that such a pre-synthetic opportunity may stretch our epistemology too far and too wide, making for a hybridisation of shallow understanding, rather than a deepening of science.

\section{Paradox}

On the other hand, it appears that postmodern episteme does hold a place for paradox similar to the presence-absence paradox found so often in traditional spiritual literature. It seems for many that our ability to hold paradox enriches our imagination of the unsayable (Franke 2006). In postmodern context, traditional usage of apophatic un-knowing in spiritual doctrine is stretched to include a rational deconstruction of paradigmatic knowledge that leads to a concomitant epistemic poverty. We are faced not only with a mystical but also epistemic un-grounding. A protoconstructive impulse must negotiate all of these obstacles, if we wish for a more coherent spiritual epistemology (Barnes 2005:32).

\section{Postmodern epistemic 'fuzziness'}

The concern for truth within philosophy and the broadest idea of science is both particular and general (Steup 2005). Whilst scientific particularity continues without a definite model or grand connecting generality satisfactory to its paradigm of investigation, the quest for a new scientific imagination seems urgent. A new synthetic meta-theory would have to work with a complexity of epistemic nuance, coming from a number of epistemic interests. At a more popular level, if one asks of the so called ' $x$ ' or ' $y$ ' generations, most would accept 
that truth is largely established in the colours of modernism, or rather, that these constitute instances of truth. Despite a generalised poverty induced from the loss of former epistemological vistas, the modernist point is taken seriously, perhaps mostly in our biological-ism (Monyaco 2006).

\section{The rise of biology and virtue, and their 'strengthening' of epistemology}

Hvolbek (1998) raises the point that decentralisation of traditional Epistemology to specialised science during the modern period, brought with it some benefit for democratised participation, and continues to do so in the specialisations of scientific realism.

Paul Griffiths (2007:1), in his article on the Philosophy of Biology, claims that 'The growth of philosophical interest in biology over the past thirty years reflects the increasing prominence of the biological sciences in the same period'. It is certainly obvious from a popular level that we envisage the language of truth and transformation in evolutionary terms. Whilst no objection to evolutionary theory per se need be raised, severe reservations (Dawkins 1976) about an evolutionary epistemology of spiritual transformation deserve to be taken seriously. Will it do to follow an assumed or imagined biological paradigm? One may freely assume some biological substrate to all things human. However, at a theoretical level, epistemic success seems to be dependent on how much flexibility is intentionally constructed into working hypotheses (Hay 2006:165-187). It is evident to me that complimenting scientific particulars, virtues and manners have become fundamental to the episteme of postmodernism and bolstered hermeneutical methodology, whilst enhancing a strong virtue ethic in methodology generally.

\section{Deconstruction, morality and convergence}

Counting the moral expense of modernism is the moral beginning-point of postmodern trend, par excellence. For instance, two relatively unrelated interests ecology and feminism, find themselves in postmodern, ideological proximity, in their mutual critique of modernist anthrocentric epistemology, which produced andro-centric manners (Zimmerman 1989). In proliferation of social evils, the 'very model of a modern major general', as expressed in HMS Pinafore (Gilbert \& Sullivan 1878), is found to disgust. The pretence of privilege and domination, an attitude of arrogance held within the modernist understanding, is a moral concern in recent postmodern methodology, politics of perfection, theories of being, and meta-reflection. Convergence of postmodern critical interests begins in deconstruction of a morally indefensible episteme. Here lies the traditional epistemological centrality: injunction to truth, which became over-delegated to experiment, lost its cohesiveness and therefore its moral or intuitive reliability.

\section{Deconstruction of paradigm and the broadening of science}

Equally, we should not be blind to the intention implicit in post-structural paradigm. The rub of paradigm is namely that it only guarantees experience in terms of its own methodology. Ken Wilber (2006), following Kuhn (1962:42$48)$, notes that paradigms follow an implicit injunction which may be expressed as: 'If you follow such and such method of investigation as prescribed by theory you will have such and such experience'. Postmodernism, primarily an analysis from the Humanities found its paradigmatic problem and mystery to be a human one. Each theory of scientific experience is specialised to find what it seeks. There can be, and indeed is, an injunction for the investigation of anything, and therefore integrational postmodern thinking accepts the validity of all paradigms for their restricted and particular field. The postmodern point suggests that science does not have to be narrowed to focus on natural visibles, nor should it escape from the moral aspects of meta-reflection and philosophy. It appears that an epistemic vulnerability in deconstructive postmodernism is its lack of a solid anthropology. There is a certain apophatic celebration to 'being lost'. The experience can be both purifying and fertile. Perhaps it is just after such a period that we engage more authentically and intelligently with the question of being, from broader tales of other sciences.

The history of Philosophy, suggests that questions of ontology and epistemology progress hand in glove. Neither contemplative meta-reflection nor hermeneutics, can avoid these. Can a purely Christian theological paradigm accommodate a broader anthropological project? Allegiance to doctrinal meta-theory seems somehow dishonest and too narrow; our ideas of truth, knowledge, being, et cetera must take their part amongst a more general science of humanity. Appreciation of this point perhaps guides those interested in broadly anthropological science and who have begun to investigate the nature of spirituality from a biological understanding of what constitutes knowledge (Hay 2006). In the broader scientific milieu, a spiritual reflection on the nature of meta-consciousness too, must find space.

\section{The deconstruction of historicised ego}

In Benedikter's (2005) Postmodern Spirituality: A Dialogue in Five Parts, the author offers a summary of the deconstructive episteme, thus:

Deconstruct everything your 'ego' thought it would be. And question everything you felt to be. Then you may discover that your normal ' $\mathrm{I}$ ' is just an illusion, a construct by cultural, social, educational, parental and historical factors. A true ' $\mathrm{I}$ ' does not exist; your normal self is just a construct, an illusion. As Jacques Derrida put it: 'What is an I or a Self? I don't know. I have never seen one'. (Benedikter 2005:iii, 1)

The logic of deconstruction exposes the character of socio-linguistic historicised-self, the ego (Hvolbek 1998) to a definite moral scrutiny, in certain ways paralleling a traditional interrogation of ego in Western and Oriental spirituality. However, if deconstruction is constitutive of the postmodern spiritual imperative, how does one deconstruct one's own subject? We can only actively and rationally deconstruct objects. The self is essentially an exception; it is 
a non-object, or subject. Benedikter (2005:iii, 1) is not slow to see the implicit tautology in Derrida's statement: 'I say to you there is, no I'. However, if one follows the logical, rational extension of Derridan deconstructive instinct, we get the picture that no ontological substantial remains, or it is suspended from formerly held notions of scientific determinism and metaphysical realism. Deconstruction delivers us to the recognition of historicised falsehood within; the presence of a false-self. Deconstruction seems then, to be a deeply emancipative impulse, the necessary prerequisite to enlightenment. Krishnamurti's (1954) 'watching the watcher, watching, the ego', describes how we can cognitively participate in a spiritual practice of ego-deconstruction for the moral and spiritual purpose of deconstructing narcissism. Krishnamurti's Oriental wisdom, rationally expressed in Western language, compels engagement with traditional Western spirituality in his deconstruction of ego.

\section{Mature postmodernism Toward neo-essentialism?}

So, where does consciousness travel, once it has deconstructed ego-attachment in the things of illusion? Benedikter's argument for a neo-essentialist movement in mature postmodernism rests on a number of literary and philosophical references. These differ in their levels and anthropological concerns. A detailed discussion of these differences is omitted in Benedikter and here, for reasons of brevity. The strand that seems common in his reading focuses on the dynamic nature of attention. Benedikter paraphrases Gebser's (1986) answer to the aforementioned question, thus: 'Quite plainly, we are still aware that the stream of consciousness continues, as act and activity, pure and active attention' (Gebser 1986; cf. also Benedikter 2005:iii, 2). What is this dynamic nothingness and borderline something-ness, which is prior to normal ego and suggests the primordial basis of consciousness? Here Benedikter cites numerous authors: Bhaskar (2002) refers to it as 'pure substance of mankind' [sic]; Derrida (1995) speaks of 'the absolute secret'; Foucault (1977) called it the 'productive void'; Heidegger (1927), 'ontological occurrence'; and Rand (1947), 'the fountainhead'. It is quite clear that in the writing of thinkers of the mature 20th century, a new essentialism suggests itself. Postmodernism perhaps, reaches its neoreligious peak in Gebser's (1986) 'permanent origin in itself' and Bhaskar's (2002) 'meta-conscious basis of postmodern emancipation and everyday life'.

After deconstructing realism and inner ego-objects, we recognise something behind the eyes (Hay 2006), which although it deconstructs, is itself resilient to deconstruction.

\section{The affirmative phenomenology of meta- consciousness, false-self and true-self}

Consciousness behind the ego suggests an inner realm of two 'I's. We are profoundly paradoxical, fragmented and schizoid, according to Benedikter (2005:iii, 4): 'If you take deconstruction seriously, you will, sooner or later, encounter the other'. Traditional mystical epistemology speaks often of a conscious, transformative embrace of the Other. Embrace of otherness that is conceivably also nothingness, seems a perennially recurrent mystical experience. In postmodern spiritual epistemology primacy is given to a rationally derived cognitive participation in deconstruction. Psychologically, unconscious expression of 'non-being' symptomatically gives rise to schizophrenia ${ }^{1}$ and narcissism in pseudo-spiritualities. Is not the unconscious pseudo-spirituality of modernism materialism? The implicit spiritual injunction to authenticity and wholeness, in various traditions would have us hold and dissolve attachment to selfish realisms, staying in the moment of terror after deconstructive process, to encounter being in a metaphorical post-annihilation. These are of course, terms used in many mystical traditions and referred to often in the writings of Merton (Cunningham 1999), Johnston (2000), Krishnamurti (1954) and Nishida Kitarô (cf. Maraldo 2005).

In his mature work (2003:5-69) published posthumously, Merton refers to the false, collective, alienated exterior and authentic, hidden, real, dark, inner, interior, inmost, awakening selves. Epistemologically speaking it is only in mature postmodernism that we have taken the rational experience of many-selves seriously: grounding real-self by un-grounding false-self. Western true-self and Oriental non-self seem parallel meta-conscious realms arrived at, in deconstructing false-selves.

\section{Essential ambivalence, Core Theory and the imagination}

Spirituality implies to me a core, which needs some theory for itself; perhaps a new spiritual anthropology? Such an enterprise is likely to take the experience of ambivalence seriously. Yet it might hope to inform an epistemology of extreme liberty. Before this possibility, it seems we are to experience ourselves as 'chronically unfulfilled' (Benedikter 2005:iii, 4) and 'open to a number of apophatic discourses' (Franke 2006).

Especially, thinks O' Donohue (2000), where neat lines of anthropology have broken down; imagination must speak of the heart, consciously: 'Imagination transfigures the big vacancies into a vital and energetic sense of absence'. This is the faithful quest suggested in postmodern spirituality: to haunt us with a myriad path of negative conviction. Psychological insight seems to suggest that authentic postmodern spirituality must turn to constructive ontology, whilst Wilber's integral instinct would have us un-ground the question of being altogether. How does one hold such an epistemic paradox, and how can one progress beyond a mere borderline language of cores? Such a tenuous position can only be exacerbated by apophatic experience and meontic (i.e. Pacific) context. Such, I believe, is the tension of creative anxiety appropriate to the hermeneutical activity of academic spirituality ${ }^{2}$.

1.The term is used in the popular sense, that is, a diachronic splitting of consciousness.

2.The stuff of spirituality is fundamentally mysterious, yet traditional descriptions abound. How are academics to make sense of the fact? And how are we to then ground our description in more philosophically rigorous terms? This is, for me, the creative anxiety in which we find our existential and epistemic quest. 


\section{A way forward?}

How might meta-reflection negotiate a proto-ontology and basis for spiritual transformation from a place of enigma? Upon reflection, if Davey (2007) is correct, in his summation of Gadamer's (1986:5-53) 'hermeneutical aesthetics' from The Relevance of the Beautiful, we might follow a hermeneutics of phenomenology. Of Gadamer, Davey (2007) claims that:

Gadamer's determination to reveal the cognitive content of aesthetic experience requires him to expose the ontological grounding of subjectivity ... The aim is to demonstrate cognitive legitimacy of subjective experience by revealing how aesthetic experience reflects a larger actuality within itself. (p. 6)

Postmodern Human Science perhaps grounds being in perception, attitudes, responses and in consciousness per se, substituting metaphysical substance with something more akin to a meta-cognitive dynamic.

From a different epistemological set, Zohar and Marshall (2001; 2005) have formulated a hybrid theory of Spiritual Intelligence and Spiritual Capital. Their meta-reflection is made up of metaphors from Quantum Physics, Chaos Theory and Complexity Science, combined with Philosophy, Psychology and Sociology. The idea that spiritual intelligence makes for a more relational consciousness is a rational intuition at the very heart of spirituality. Reclamation of rational intuition as a constructive epistemic virtue appears to bare theoretical fertility. I believe the constructive heart of hermeneutics is to effect human transformation with every intelligent tool at its disposal. How might a meta-theory describe a methodology incorporating all intelligible things? It appears that for all the talk of hermeneutics, very little is substantive or measurable. Perhaps this the most pressing reason to include anthropological understandings within dynamics of transformation. I suspect that, like the proverbial 'finger pointing to the moon', the role of hermeneutics is not only a 'whole-person' engagement with text, but also points away from itself to both the broad and deep epistemological context of the individual enquiry.

\section{Some epistemic concerns}

As Lesniak (2005) writes:

... the postmodern consciousness acknowledges 1 . The organic and limited nature of the world itself and the interdependency of the human species with all that exist; 2. the ambiguous and multifaceted character of human consciousness and the recognition of the partial, conditioned reality of all truth claims; 3. the awareness that the human person is not self-contained but internally constituted by a whole range of relationships. (p. 7)

For her, the oughts of postmodern sensibility arise in a mixture of cares-out-of-crisis: deep ecology, human consciousness, human character, broad epistemology (including personal epistemes), complexity, context, conditioning, et cetera. No exhaustive list exists to my knowledge. However, the point is this: complexity in the world of epistemology is par for the course and we need the insights of as many specialised epistemologies as possible, for two reasons:

1. Spirituality must offer some promise to broaden and 'fill out' our understanding of being and anthropology. For me, academic spirituality ought to earn its stripes as a human story in a world of science.

2. Following then, academic spirituality requires an epistemology larger than purely those of the Humanities.

Postmodern instincts to reclaim epistemic attitudes formally alienated by modernism provide a deep philosophical legitimacy to a methodology that is both scientific and includes affectivity, rational intuition, transformation, integral thinking, creativity, relational consciousness and authenticity. Being a scientist of spirituality means to be possessed of the 'more than'. Methodological questions not only follow hard, but also are intertwined in the act of contemplative study and transformation.

\section{Neo-essentialism: Ontology from cognition?}

An idea emerges from the postmodern spiritual turn of a spiritual core, place or being, legitimately the primary concern of theoretical spirituality. For Benedikter (2005:iii), from the moment of cognitive resistance to deconstruction, we speak of a felt ontology, of 'something there', yet this 'something' remains more than dimensional phenomena, an ontic witness which is separated from the ego by a productive void, and which acts on this productive void as to compel our self-experience to a higher status in an instantiation of being (Cupitt 1998). For purposes of ease, we may here refer to this as the human spirit. How may we describe such a thing? Perhaps the primary phenomenon to begin with is its profound consciousness. Does this mean that human spirit is the residence of proto-intelligence? Potentially unformed ontic intelligence is prototypical but not inferior to the rational intelligence of ego-state. Could we then surmise that as deep intelligence, spirit participates with and knows things of life in a way far more profoundly, synchronically or intuitively, than rational knowledge alone? What then lies in store for an epistemology of deep ecology (Zimmerman 1989)? Could we then compare spirit with the realm of the unconscious to find some significant difference between spirituality and positive psychology? It seems adequately clear that in the Freudian (1994) model, personality arises from an ontic position of unawareness, unconsciousness, and narcissism. I think we can see that constructive potential for paradigms, theory and episteme, clearly. Yet how might we ground spirit in the rawness of its fundamental process?

\section{Intelligence, inspiration and transformation}

Benedikter (2005:v, 13-19) suggests that inspiration is a peak experience of intelligence. The argument specifies that moral core is fundamental to the philosophy of postmodernism because:

- As a push beyond modernism, postmodernism has internalised subject-object dichotomy and come to an irreducible diachronic relationship between observer and ego (the postmodern schizoid event). 
- Because this reality is the one from which thinking can become aware of itself, the postmodern enlightenment or altered state is an extension of rationality, to the preverbal experience of thinking.

- Postmodern virtue, in the process of thinking, is inspiration.

Not having an object, inspiration evokes a strengthened awareness of its own creative attention process (Benedikter 2005:v, 13-19). It assumes an all-encompassing virtue. Inspiration comes to be the keeper of the movements, the virtue of being conscious. A far greater picture emerges if we reclaim insights from Virtue Theory, Transcendence Theory and various models of transformation. Whatever theoretical paradigms are forthcoming, they would have to proffer some explanation of psychological availability to transformative inspiration. Paradoxically ontological grounding lies in a process of ontological suspension.

\section{Complexity of postmodern religious-core and Psychology}

Dealing with complex science is not easy nor is an adequate description of spiritual and moral transformation and how we might easily deconstruct the conventional within in order to begin reconstructing the substantiation of a new caring order. It might, though, follow a line of reasoning which goes something like this:
... if I begin to understand what crudeness is, observe it in my life from day to day - the greedy way I eat, the roughness with which I treat people, the pride, the arrogance, the coarseness of my habits and thoughts - then that very observation transforms what is. Similarly ... what is important is to understand stupidity - how I behave towards my servant, how I regard my neighbour, the rich man, the poor man and the clerk - this awareness brings about a breaking up of stupidity. (Krishnamurti 1954:65 [emphasis not author's own])

How might such a working hypothesis find itself accommodated within an epistemology of mysticism? From a positivist context, it is not easy to 'work with' apophasis and deconstruction, yet it appears to me that this is the vocation of academic spirituality science itself.

\section{Postmodern examination of religious consciousness}

Through designed intention-practice, or the gift of external encounter, true thinking happens. This process conceivably begins an internal reflexive development for its own intelligent and intelligence-seeking agenda, or selfknowledge. Deconstruction of false-self dichotomy into pureunitive-experience of synchronic attention may produce catharsis, and/or connective insight. It is conceivable that insight, a moment of eros, may feel like an embrace of totality in the mystery of being, issuing bliss, rapture, love or enlightenment - a mystical instantiation of being. At this state, the ground of being or the productive void becomes the parental fountainhead of inspiration. Following hard on nondimensional (the ineffable?) experience, consciousness begins an attentive turn outward, which is completed in self- forgetful, kenotic being in the world and which instantiates authentic being, originality and inspired intelligence in the world. Inspiration may be thus considered simultaneously meta-rational (pre-conceptual) and rational. Inspiration is precise and productive and calls many of us (Lesniak 2005) to a definite contemplative practice. As Monyaco (2006:4) writes, 'contemplative prayer is a prayer of aspiration and realization of the sacred as the emptiness which lies beyond the representation'. Equally, Lesniak (2005:8) notes the contemporary 'appeal' of themes like 'transformation, solitude, interiority, the search for wisdom, contemplative prayer and spiritual growth'.

In presenting these hypothetical possibilities, my intention is to be as broadly anthropological as possible, seeking to emphasise this point: if academic spirituality is to earn its stripes in the sector we call Human Sciences; its methodology must go beyond a hermeneutical engagement with traditional text.

\section{Postmodern engagement with Tradition}

Some traditional mystic doctrines - including the darknight (John of the Cross), ground of being (Meister Eckhart), cloud of unknowing (anononymous, perhaps 14th century English Carthusian) and various mystics of light - can potentially find accommodation in postmodern and protoanthropological terminology. The contents of traditional mysticism - deconstruction of the false-self in ineffable and apophatic connectivity (union) - seem to anticipate a prototheory of postmodern mysticism. As a proto-spirituality, Bianchi (1991) reminds us that postmodern spirituality is trans-traditional, a fact also indicated by the inter-religious dynamic in contemporary spiritual practice. Postmodernism has a taste for the exemplary, but not much for superlatives or absolutes in traditional-religious ascriptions. Postmodern spirituality is not so much demythologised as alternatively mythologised into the academic world of science. William Franke (2006) claims a historical progression from negative theology to negation of theology in postmodern apophatic spirituality. Devolution of spirituality from theology seems a consequence of the rise of liberal Humanities in the epistemology of the West. Slife and Scott Richards (2001:190 205) suggest that spirituality is still tied to theological apronstrings. Factors that produce tension are the heightened sense of democracy and humanism, and the reduced (poststructural) sense of history as well as a number of sociological factors (Finnegan 2010:27-37).

\section{Conclusion}

\section{The character of postmodern spiritual episteme}

Post structural neo-essentialism poses a sense of human growth, felt to be organic and fluid. It might be said to exhibit itself as sociologically messy, experiential, multifaceted, ecological, provisional and collective (Petrolle 2007). However, Benedikter's conception of mature postmodernism helps us see postmodern spirituality as an epistemological 
possibility authentically in line with an existential and phenomenological reclamation of traditional spiritual doctrine removed from theology.

The challenge for postmodern spirituality lies within its vulnerability, within its regressive and narcissistic elements. Central to postmodern ascription and construction is a profound ambivalence towards articulation; it seems naturally apophatic in object and subject (Howells 2005). Profoundly different to the pre-modern and modernist dogmatic style, postmodernism tends to cower from preaching and teaching an experience, preferring to create spaces for groups and individuals to have their own. Inspiration lies not inside the ground of being in a traditional sense, but arises out of a rationally observable tension of productive anxiety. Intelligence and inspiration are co-terminus, co-temporal, co-existent and interdependent, ontologically dynamic. Inspiration, neither presupposes prior intelligence nor can it be un-intelligent; rather it is like an enfoldment (Kitarô in Maraldo 2005:18) of intelligence and is therefore not independent of intelligence.

Postmodern spirituality may thus be said to be a religion of immanence where Adorno and Horkheimer's (1947) insight is taken seriously: 'Metaphysics has moved into micrology ... No Absolute can be expressed differently than in things and through categories of immanence [which provide] a readable constellation of existence' (Adorno \& Horkheimer 1947).

Evidence of micrology and nanology in the specialisations of natural science is clearly visible. At a lay level, micrology may be the instinct behind a religion of the Immanent and the immanent. It is in the phenomenology of the immanent from which Gadamer (1986) would have us encounter the 'more than'.

The options for spiritual typology are many: Petrolle (2007) speaks of empowering 'allegories of un-faith searching for faith'. Butler (1990) 'unclothes and un-genders consciousness'. Nolan (2006:126) participates in 'globalization from below'; Derrida (1995) in 'protecting the Secret from the violation of language', whilst Zimmerman (1989:1) speaks of 'deep ecology', Krishnamurti (1954) of 'original intelligence' and Benedikter (2005:45) of 'inspiration'.

Postmodern spirituality, its slender lines filled with deontic holes, seems nebulous, ephemeral and empty. Without certainty in ontology or teleology, we are beckoned to lives of active imagination and integral thinking. Our vulnerability to absence is an apophasis of our craving for presence in an expanding cosmos. Inspiration reveals presence in a postmodern mind. Perhaps imagination is most apposite in the way it articulates the unknown, in the un-sayable realm of the witness, to enact a re-enchantment with the good, the true and the beautiful. Postmodern spirituality certainly embraces the exemplary. There is an imperative to become more through a deconstructive becoming less, instantly and instinctively integrative. Postmodernism has, to my mind, brought us to rational and irreducible awareness of time transcending 'witness'. In contradiction of egoistic selfconcept, true-being refuses to narrate itself (Cupitt 1998). Postmodern spirituality is most radically a religion-ofimmanence. The anthropological interrogative 'who am I?' in postmodernism is unfathomable but palpable at every turn. I would claim that we generally recognise the historydissolving imperative in Benedikter's witness and in mystical spirituality itself. We may legitimately enquire (in paraphrase of O'Donohue 2000): 'Where am I absent, when I am in the ego of absolutised cognitive contrivance called history?'

On a phenomenological level, postmodern spirituality shows similarity to many others that are without traditional religious meaning ascription. As a proto-spirituality it is trans-traditional and is served best by broad definitions, such as that by Schneiders (2005:1), who defines spirituality as: 'conscious involvement in the life integration through self-transcendence toward the ultimate value one perceives'. Correspondingly, we might come to an idea of postmodern spirituality as a religiously held concern wherein belief is evolutionary; teleology is cognitive, developmentally held as biological good; its moral imperative, ecologicalrelational; and its agenda integrational. Postmodern spiritual awareness is scientific and primordial, originating in the bio-cognitive 'fact' of creative void. Postmodern spiritual practice is cognitive, contemplative, rational and engaged and intelligence seeking. Postmodern cults are decentralised and pluriform; the spirit is inspirational, imaginative and registered in bio-rational-affect, yet at its source, it is ambivalently de-constructive and mildly re-constructive. Mystical experience is ineffable and deconstructive of context, whilst its spirituality or lived religion is of immanence; its ultimate religious value is a re-enchantment with being. Postmodern institutions are democratic, plural and academic and its languages are somewhat apophatic; its end-state is enlightenment, creativity and holistically relational. Postmodern faith, hope and joys are those of life, posing the need for compassion and a method of hermeneutical engagement along all quadrants and lines of connectivity. Essentially postmodern spirituality is the spirituality of humanity standing naked before its own traumatised poverty of explanation. It may in many ways be a continuation of a spirituality of poverty in the 'new mysticism' of the 13th century (cf. McGinn 2005:20) recapitulated in Johnston's (2000:87-201) contemporary 'new mysticism'. Postmodern spirituality plainly anticipates a richer and integralist wardrobe at many levels. As a trans-traditional spirituality, it is perhaps best described by Krüger (2006) as an 'orientation' of the world into mysticism.

\section{Acknowledgements Competing interests}

The author declares that he has no financial or personal relationship(s) which may have inappropriately influenced him in writing this article. 


\section{References}

Adorno, T. \& Horkheimer, M., 1947, Dialectic of enlightenment: Philosophical fragments, transl. E. Jephcot \& S. Noerr, Stanford University Press, Stanford.

Barnes, M., 2005, 'Spirituality and the Dialogue of Religions', in The new SCM dictionary of Christian spirituality, pp. 32-37, SCM Press, London.

Benedikter, R., 2005, Postmodern spirituality: A dialogue in five parts, viewed 08 October 2009, from http://www.integralworld.net/benedikter5.html

Bhaskar, R., 2002, The philosophy of meta-reality, Sage, London.

Bianchi, E., 1991, Trans-traditional spirituality: Priest/minister as spiritual seeker viewed 20 October 2009, from http://religion.emory.edu/faculty/bianchi/ corpus 97. htm

Bird, A., 2004, 'Thomas Khun', in Stanford encyclopedia of Philosophy, viewed 09 September 2009, from http://plato.stanford.edu/entries

Bradie, M. \& Harms, C., 2008, 'Evolutionary Epistemology', in Stanford encyclopedia of Philosophy, viewed 19 September 2009, from http://plato.stanford.edu/entries

Butler, J., 1990, Gender trouble: Feminism and the subversion of identity, Routledge, NY.

Corkery, J., 2005, 'Spirituality and Culture', in The new SCM dictionary of Christian spirituality, p. 26, SCM Press, London.

Crain, W., 1985, Theories of development, Prentice Hall, London.

Cunningham, L., 1999, Thomas Merton and the monastic vision, William B. Eerdmans Publishing Company, Cambridge.

Cupitt, D., 1998, The religion of being, SCM Press, London.

Davey, N., 2007, 'Gadamer's hermeneutical aesthetics', in Stanford encyclopedia of Philosophy, viewed 19 September 2009, from http://plato.stanford.edu/entries

Dawkins, R., 1976, The selfish gene, Oxford University Press, Oxford.

Derrida, J., 1995, On the name, transl. D. Wood, Stanford University Press, Stanford.

Foucault, M., 1977, Discipline and punish: Birth of the prison, transl. A. Sheridan, Vintage, NY.

Franke, W., 2006, Apophasis and the turn in philosophy of religion from neoplatonic negative theology to postmodern negation of theology, viewed 20 October 2009, negative theology to postmodern $n$ from http://www.springerlink.com
from

Freud, S., 1994, The interpretation of dreams, transl. A. Brill, Barnes and Noble, London.

Gadamer, H., 1986, The relevance of the beautiful and other essays, Cambridge University Press, London.

Gebser, J., 1986, The ever present origin, Ohio University Press, NY.

Griffin, D., 1990, 'Redefining the Divine: An Interview with David Ray Griffin by Alan At Kissson', in Earth Spirit, Winter 20, viewed 09 October 2009, from http://www. context.org/ICLIB/IC24/Griffin.htm

Griffiths, D., 2007, 'Philosophy of Biology', in Stanford encyclopedia of Philosophy, viewed 09 October 2009, from http://plato.stanford.edu/entries

Hay, D., 2006, Something there: The biology of the human spirit, Darton Longman and Todd, London.

Heidegger, M., 1962, Being and time, transl. J. Maquarrie \& E. Robinson, Harper and Row, NY.
Howells, E., 2005, 'Apophatic Spirituality', in The new SCM dictionary of Christian spirituality, p. 117, SCM Press, London.

Hvolbek, R., 1998, Mysticism and experience, University of America Press, MD.

Johnston, W., 2000, 'Arise my Love ...': Mysticism for a new era, Orbis, NY.

Kuhn, T., 1962, The structure of scientific revolutions, University of Chicago Press, IL.

Krishnamurti, J., 1954, The first and last freedom, Harper Collins, San Francisco, CA.

Kruger, J., 2006, Sounding unsound: Orientation into mysticism, Aurora Press, Wierda Park.

Lesniak, V., 2005, 'Contemporary Spirituality', in The new SCM dictionary of Christian spirituality, p. 7, SCM Press, London.

Maraldo, J., 2005, 'Nishida Kitarô', in Stanford encyclopedia of Philosophy, viewed 12 October 2009, from http://plato.stanford.edu/entries

McGinn, B., 2005, 'Mysticism', in The new SCM dictionary of Christian spirituality, p. 19, SCM Press, London.

Moncayo, P., 2006, Psychoanalysis and postmodern Spirituality, viewed 12 October 2009, from http://www.psychandpostmodernism.mht

Mouton, J., 2001, How to succeed in your masters \& doctoral studies: A South African guide and resource book, Van Schaik, Pretoria.

Nolan, A., 2006, Jesus today, Double Story, Cape Town.

O'Donohue, J. 2000, 'The Philosophy of Absence', in The Open Mind Lectures, audio DVD, Trinity College, Dublin.

Petrolle, J., 2007, Religion without belief: Contemporary allegory and the search for postmodern faith, University of New York Press, NY.

Rand, A., 1947, The Fountainhead, Bobbs-Meril, IN.

Schneiders, S., 2005, 'Christian spirituality: Definition, methods and types', in The new SCM dictionary of Christian spirituality, p. 1, SCM Press, London.

Sheldrake, P., 2005, 'Cyberspace and spirituality', in The new SCM dictionary of Christian Spirituality, p. 22, SCM Press, London.

Sheldrake, P., 2005, 'Spirituality and history', in The new SCM dictionary of Christian spirituality, p. 38, SCM Press, London.

Slife, D. \& Scott Richards, P., 2001, 'How separable are spirituality and theology in psychotherapy', in R. Balkin (ed.), Counselling and values, vol. 45, pp. 190-205.

Steup, M., 2005, 'Epistemology', in Stanford encyclopedia of Philosophy, viewed 08 October 2009, from http://plato.stanford.edu/entries

Wilber, K., 1995, Sex, ecology, spirituality: The spirit of evolution, Shambhala, Boston, MA.

Wilber, K., 2006, Spirituality and the three strands of deep science, viewed 20 October 2009, from http://www.integralinstitute.com/kenwilber

Zimmerman, M., 1989, 'Introduction to deep ecology: An interview with Michael E. Zimmerman by Alan AtKisson', in Global Climate Change, Summer 24, viewed 20 October 2009, from http://www.context.org/ICLIB22/Zimmerman.htm

Zuidervaart, L., 2007, 'Theodor Adorno', in Stanford encyclopedia of Philosophy, viewed 20 October 2009, from http://plato.stanford.edu/entries

Zohar, D. \& Marshall, I., 2005, Spiritual capital: Wealth we can live by, Bloomsbury, NY.

Zohar, D. \& Marshall, I., 2001, SQ - Spiritual intelligence: The ultimate intelligence, Bloomsbury, NY. 